\section{Quality parameters of hunted game meat: Sensory analysis and $\mathrm{pH}$ monitoring}

Roberto Viganò, ${ }^{1,2}$ Eugenio Demartini, Fiammetta Riccardi, ${ }^{4}$ Annafrancesca Corradini, ${ }^{3}$

Martina Besozzi, ${ }^{2}$ Paolo Lanfranchi, ${ }^{5}$

Pietro Luigi Chiappini, ${ }^{6}$

Andrea Cottini, ${ }^{1}$ Anna Gaviglio ${ }^{3}$

${ }^{1}$ Ars. Uni. VCO, Domodossola (VB);

${ }^{2}$ AlpVet Associated Office, Busto Arsizio

(VA); ${ }^{3}$ Department of Health, Animal

Science and Food Safety, University of

Milan; ${ }^{4}$ Department of Agricultural and

Environmental Sciences - Production,

Landscape, Agroenergy, University of

Milan; ${ }^{5}$ Department of Veterinary

Medicine - University of Milan;

${ }^{6}$ Chiappini Chemical Studio, Arona

(NO), Italy

\section{Abstract}

The aim of the present research is to propose a new, quick and objective method for the certification of hunted and/or culled wild game meat quality and to monitor its origin and the hunting practices adopted by hunters. The expected deliverable is a new labelling scheme for Italian hunted wild game meat that will guarantee high quality and safety standards for consumers and will decrease transaction costs of the supply chains. During the 2015, 2016 and 2017 hunting seasons, 1,056 hunted wild ungulates were sampled. Specifically, alpine chamois $(n=537)$, roe deer $(n=113)$, red deer $(n=342)$ and wild boar $(n=64)$, which were all hunted in the VCO2-Ossola Nord hunting district (Verbania Province, Piedmont, Italy). Samples of the longissimus dorsi were collected to evaluate the nutritional parameters and the acid profiles of the products. As a measure of meat quality, $\mathrm{pH}$ values have been recorded after slaughtering by inserting a probe in the semimembranosus muscle. The results were categorized as DFD $(\mathrm{pH} \geq 6,2)$, intermediate DFD $(5,8 \leq \mathrm{pH}<6,2)$ and high-quality meat $(\mathrm{pH}$ $<5,8)$. As explanatory variables for the quality of wild game meat, differences based on age, gender and hunting practices were considered. Concerning the latter variables, measures were collected from animals received at hunting districts control centers by trained technicians who also collected information on the hunting practices, i.e., bleeding and evisceration of the carcasses and number of shots. Nutritional values showed low fat ( $<3 \mathrm{~g}$ per $100 \mathrm{~g}$ ), low satu- rated fat $(<1,5 \mathrm{~g}$ per $100 \mathrm{~g})$ and high protein contents. Furthermore, wild game meat has high values of $\omega 3$ and CLA, ensuring a positive $\omega 6 / \omega 3$ ratio. Differences were found in the concentrations of fat between age and gender, considering that during the mating season, adult males' weight loss can exceed $40 \%$. Hunting practices seem to affect meat quality.

\section{Introduction}

The possibility of placing wild game meat on the market according to Reg. (EC) n. 853/2004, which considers the hunter a primary producer, represents an added value for the sustainable use of ungulates as resources in rural areas with a potential economic impact on the local economy (Gaviglio et al., 2017; Gaviglio et al., 2018). In recent decades, ungulates have shown a remarkable demographic increase in Italy, especially for red deer (Ramanzin et al., 2010) and wild boar, which is often considered more a damage than a resource (Ferri,

1998).

Game meat presents interesting nutritional and sensorial qualities. Generally, game meat has a low-fat content, although some variations related to gender, age, physiological conditions and hunting season may occur (Ramanzin et al., 2010; Russo, 2005); the amount of calories and cholesterol is low, but it has good protein, iron, zinc, vitamin B12 and some polyunsaturated fatty acid contents. Several studies have shown that wild ruminant fat has a favourable ratio of $\omega 6 / \omega 3$ fatty acids (Valencak et al., 2015), with a good conjugated linoleic acid (CLA) content (Secchiari et al., 2001; Phillip et al., 2007). Due to both its peculiar intrinsic and extrinsic features, the consumer trend of game meat is rapidly growing (Piasentier et al., 2005; Demartini et al., 2018; Marescotti et al., 2019).

The market availability of free ranging game meat culled according to hunting management plans requires detailed monitoring for its nutritional, sensorial and sanitary quality; moreover, monitoring is necessary to guarantee safety, quality and traceability requirements to the new game meat supply

chain.

The use of good hunting practices (immediate death, bleeding and immediate evisceration, proper transport) are therefore functional to guarantee low levels of microbial contamination and preserve both meat hygiene (Hoffman \& Wiklund, 2006; Gill, 2007; Atassanova et al., 2008; Winkelmayer \& Paulsen, 2008; Paulsen et al., 2011; Avagnina et al., 2012; Liepina et al., 2010) and sensory qualities (Postolache
Correspondence: Roberto Viganò, Piazza Venzaghi, 2 Busto Arsizio (VA) Italy.

E-mail: r.vigano@alpvet.it

Key words: Game meat, pH, Fatty acids.

Contributions: the authors contributed equally.

Conflict of interest: the authors declare no potential conflict of interest.

Funding: this research was funded by Fondazione Cariplo "Bandi Ambiente 2014 Progetto La Filiera Eco-Alimentare - Progetto per la valorizzazione delle carni di selvaggina: la gestione di un prodotto sostenibile come strumento di stimolo al miglioramento ambientale dei territori alpini".

Received for publication: 27 July 2018.

Revision received: 19 February 2019.

Accepted for publication: 25 February 2019.

This work is licensed under a Creative Commons Attribution-NonCommercial 4.0 International License (CC BY-NC 4.0).

(C) Copyright R. Viganò et al., 2019

Licensee PAGEPress, Italy

Italian Journal of Food Safety 2019; 8:7724

doi:10.4081/ijfs.2019.7724

et al., 2011; Soriano et al., 2016).

The $\mathrm{pH}$ value of meat (initial and final $\mathrm{pH}$ and decrease rate of $\mathrm{pH}$ ) is one of the most important indicators of the effect of pre-mortem stress on meat quality (Lawrie, 2006). For this reason, the implementation of this method for hunted animals could be an instrument to verify the real acidification of muscles and the right implementation of hunting best practices (Wiklund et al., 2004; Lonergan et al., 2010).

The decrease in $\mathrm{pH}$, occurring in the early hours after death, can provide useful information on the stress conditions of the animal before shooting and bleeding procedures (Hoffman \& Ferreria, 2000). Moreover, the impact of the reproductive cycle, for example, a rapid weight decrease in adult males after the mating season, may modify the $\mathrm{pH}$ decrease (Viganò et al., 2017).

\section{Materials and Methods}

In 2015, the project "Filiera EcoAlimentare" was initiated with the aim of promoting local game meat by improving its hygiene and health quality as well as to create an origin brand and the promotion of local food and tourism in High Ossola Valley (area of Verbania, Piedmont, Italy). In this study, the nutritional parameters of 
game meat were analyzed, and the critical issues related to culling, evisceration and transport of ungulates as part of hunting management plans were assessed.

The study area was the VCO2-Ossola Nord hunting district located in the north of Verbania. The number of wild ungulates each hunter can shoot was set based on the annual census and the trend of the previous hunting season and it must be approved by the Piedmont Region. The wild ungulates were delivered on the same day of hunting to hunting district control center where morpho-biometric measurements and scientific data were collected by qualified technicians (free-lance veterinarians). For each animal species, gender, age class, time and place of shooting, type of culling, time to death (divided into three categories: dead on the spot, less than five minutes, more than five minutes), number of shots, points of entry and exit of shots, type of bleeding and evis- ceration, abdominal lesions, body condition and morpho-biometric measurements (weight, mandible and tarsus length, and trophy measurements) were collected.

Simultaneously, $\mathrm{pH}$ measurements and temperatures of semimembranosus muscles were collected with an HD2105.2 Delta $\mathrm{OHM}{ }^{\circledR}$ instrument with a precision of $\pm 0,001 \mathrm{pH}$ units. Measurements were recorded during the same hour of collection, which could be several hours or shortly

Table 1. Grams of moisture, protein, fats, crude ash in $100 \mathrm{~g}$ of game meat.

\begin{tabular}{|c|c|c|c|c|c|c|c|c|}
\hline \multirow[t]{2}{*}{$\mathrm{g} / 100 \mathrm{~g}$} & \multicolumn{2}{|c|}{ Chamois } & \multirow{2}{*}{$\begin{array}{l}\text { Roe deer } \\
\text { Adult } \\
\text { males }\end{array}$} & \multirow[b]{2}{*}{ Yearlings } & \multicolumn{2}{|c|}{ Red deer } & \multirow[b]{2}{*}{$\begin{array}{c}\text { Adult } \\
\text { females }\end{array}$} & \multirow{2}{*}{$\begin{array}{c}\text { Wild boa } \\
\text { Adult } \\
\text { males }\end{array}$} \\
\hline & Yearlings & $\begin{array}{l}\text { Adult } \\
\text { males }\end{array}$ & & & $\begin{array}{l}\text { Sub-adult } \\
\text { males }\end{array}$ & $\begin{array}{l}\text { Adult } \\
\text { males }\end{array}$ & & \\
\hline Moisture & 74,52 & 78,10 & 75,00 & 71,68 & 74,10 & 74,26 & 74,39 & 71,55 \\
\hline Protein & 22,40 & 19,10 & 21,90 & 21,70 & 23,30 & 24,10 & 21,90 & 24,70 \\
\hline Fats & 1,40 & 1,38 & 1,95 & 5,09 & 1,06 & 0,25 & 2,32 & 2,26 \\
\hline Crude ash & 1,31 & 1,24 & 1,04 & 1,39 & 1,34 & 1,25 & 1,23 & 1,21 \\
\hline
\end{tabular}

Table 2. Acid composition as \% of lipidic fraction.

\begin{tabular}{|c|c|c|c|c|c|c|c|c|}
\hline \multirow[t]{2}{*}{$\mathrm{g} / 100 \mathrm{~g}$} & \multicolumn{2}{|c|}{ Chamois } & \multirow{2}{*}{$\begin{array}{l}\text { Roe deer } \\
\text { Adult } \\
\text { males }\end{array}$} & \multicolumn{4}{|c|}{ Red deer } & \multirow{2}{*}{$\begin{array}{l}\text { Wild boar } \\
\text { Adult } \\
\text { males }\end{array}$} \\
\hline & Yearlings & $\begin{array}{l}\text { Adult } \\
\text { males }\end{array}$ & & Yearlings & $\begin{array}{l}\text { Sub-adult } \\
\text { males }\end{array}$ & $\begin{array}{l}\text { Adult } \\
\text { males }\end{array}$ & $\begin{array}{c}\text { Adult } \\
\text { females }\end{array}$ & \\
\hline C 8:0 & & & 0,01 & & & & & \\
\hline C 10:0 & & & 0,05 & & & & & 0,09 \\
\hline C 12:0 & & & 0,01 & 0,26 & 0,37 & 0,52 & 0,35 & 0,10 \\
\hline C 14:0 & 1,99 & 1,37 & 2,47 & 5,54 & 6,14 & 5,42 & 5,75 & 1,42 \\
\hline C 14:1 & & 0,01 & 0,07 & 1,31 & 0,79 & 0,84 & 0,91 & \\
\hline C 15:0 & 2,76 & 1,77 & 0,92 & 0,97 & 1,12 & 1,65 & 1,42 & 0,01 \\
\hline C 16:0 & 20,25 & 13,72 & 26,63 & 29,66 & 29,41 & 27,67 & 27,96 & 24,58 \\
\hline C 16:1 & 1,25 & 0,85 & 1,46 & 7,25 & 4,04 & 5,71 & 5,67 & 3,24 \\
\hline C 17:0 & 1,94 & 14,65 & 1,94 & 0,96 & 1,07 & 1,25 & 1,15 & 0,20 \\
\hline C 17:1 & 0,31 & 0,15 & 0,42 & 0,32 & 0,19 & 0,26 & 0,27 & 0,15 \\
\hline C 18:0 & 26,84 & 23,00 & 27,99 & 20,19 & 27,59 & 30,81 & 23,22 & 11,02 \\
\hline C 18:1 n-9 & 23,41 & 41,47 & 28,44 & 20,03 & 17,60 & 14,86 & 18,05 & 35,33 \\
\hline C 18:1 n-7 & 7,71 & 1,28 & 3,44 & 6,75 & 5,95 & 6,30 & 7,44 & 3,94 \\
\hline C $18: 2$ n-6 & 8,70 & 0,83 & 3,46 & 2,76 & 2,64 & 2,11 & 3,38 & 15,57 \\
\hline C 18:3 n-3 & 3,82 & 0,35 & 1,04 & 1,45 & 0,99 & 1,04 & 1,75 & 1,98 \\
\hline C 18:3 n-6 & 0,35 & 0,08 & 0,23 & 0,47 & 0,29 & 0,37 & 0,46 & 0,10 \\
\hline C 18:4 n-3 & & & & 0,64 & 0,55 & 0,51 & 0,57 & 0,01 \\
\hline C 20:0 & 0,36 & 0,10 & 0,24 & 0,45 & 0,75 & 0,48 & 0,73 & 0,23 \\
\hline C 20:1 n-9 & & 0,13 & 0,14 & 0,31 & 0,17 & 0,11 & 0,15 & 0,79 \\
\hline C 20:2 n-6 & & & & 0,11 & & & 0,09 & 0,47 \\
\hline C 20:3 n-6 & & & & 0,07 & 0,19 & 0,09 & 0,08 & 0,07 \\
\hline C 20:3 n-3 & & & & 0,07 & & & 0,10 & 0,21 \\
\hline C 20:4 n-6 & & & 0,29 & 0,21 & & & 0,18 & 0,26 \\
\hline C 20:5 n-3 & & & & 0,10 & & & 0,08 & \\
\hline C 22:0 & & & & 0,09 & 0,15 & & 0,13 & \\
\hline C 22:1 n-11 & & & 0,01 & & & & & \\
\hline C 22:2 n-6 & & & 0,01 & & & & & \\
\hline C 22-6 n-3 & & & & 0,01 & & & & \\
\hline C 24:0 & & & & & & & 0,09 & \\
\hline CLA & 0,31 & 0,21 & 0,61 & & & & & 0,18 \\
\hline
\end{tabular}


after death. During 2015, 2016 and 2017 hunting seasons, a total of 1,056 ungulates were collected (537 chamois, 113 roe deer, 342 red deer and 64 wild boars), among which 1,027 presented a complete data collection ( 525 chamois, 108 roe deer, 332 red deer and 62 wild boars). The $\mathrm{pH}$ values collected 240 minutes after culling were considered predictive of the quality of the meat according to (Hoffmann \& Ferreria, 2000; Wiklund et al., 2004), considering a $\mathrm{pH}$ $>6.2$ DFD, a $5.8>\mathrm{pH}>6.2$ as intermediate DFD, and a $\mathrm{pH}<5.8$ as good quality. Data were analyzed with statistical software (IBM ${ }^{\circledR}$ SPSS ${ }^{\circledR} 21.0$ ). For statistical purposes, variables were compared with a univariate analysis. Significance was considered for P-values $<0.05$.

Samples $(\mathrm{N}=8)$ of the Longissimus dorsi muscle were also collected from chamois, roe deer, red deer and wild boars to evaluate nutritional parameters and acid profiles and consequently to identify any differences between age classes and gender of the different hunted ungulates. A 150/200 g sample was collected at the game processing center the day after slaughter, refrigerated at a temperature below $4^{\circ} \mathrm{C}$ and delivered to the laboratory for analysis. For each sample, moisture (AOAC 950.46 B 1991), protein (AOAC 992.15 1992), fat
(AOAC 960.39 B) and crude ash (UNI 10590:1997) contents were tested. The fatty acid composition was identified by GC FID (MP-2097 rev. 02013 - [UNI EN 1528 - 2: 1997] + AOAC 991.39 1995).

\section{Results}

Results for nutritional values per $100 \mathrm{~g}$ of product show high protein content (average $22,39 \mathrm{~g} \pm 1,727 \mathrm{std}$. dev.), low fat content (average 1,96 $\mathrm{g} \pm 1,434 \mathrm{std}$. dev.) and an ash value average of $1,25 \mathrm{~g} \pm 0,105 \mathrm{std}$. dev. (Tables 1 and 2).

The saturated fatty acid content per 100 $\mathrm{g}$ of product was low $(1.10 \mathrm{~g} \pm 0.835 \mathrm{std}$. dev.), and more specifically, a lower ratio of $\omega 6 / \omega 3$ (on average $2.25 \pm 0.793$ std. dev.) was observed in ruminant ungulates than in wild boars. In addition, differences in the concentration and acid composition between species, age classes and sex were observed. The value of fats in adult red deer males was significantly lower than in the other classes of the same species (Table 3).

Considering $\mathrm{pH}$ measurement as a forecasting parameter to evaluate the quality of meat, $\mathrm{pH}$ values were recorded within 240 minutes of culling and after 240 minutes of culling, the results were classified as good
$(\mathrm{pH} \quad<5,8), \quad$ intermediate-DFD $(5.8<\mathrm{pH}<6.2)$ and DFD $(\mathrm{pH}>6.2)$. Additionally, animals killed and managed according to best hunting practices (dead on the spot and bled immediately) were compared to those not managed according to the best practices (Table 4). The $\mathrm{pH}$ values recorded for the 4 species of wild ungulates were analysed. The results showed a large difference between quickly and correctly bled animals compared to those not properly bled 240 minutes after slaughter. Time to death categories did not have a significant influence on the change in individual $\mathrm{pH}$, but a long time to death in association with no bleeding caused the $\mathrm{pH}$ values to differ (Table 5). Moreover, the effect of the time between the shot and the animal's death has a positive influence in association with good management practices $(\mathrm{P}<0.05)$, even if the effect could not be used as a significant single parameter in the $\mathrm{pH}$ analysis (Figures 1 and 2). In the first 4 hours after the slaughter, the decrease in the $\mathrm{pH}$ value, was faster in carcasses managed according to good practices. Furthermore, carcasses managed according to "best practices" showed $\mathrm{pH}$ stability, with values mostly lower than 5,8, while carcasses not managed properly showed a higher rate of decreasing $\mathrm{pH}$ values.

Table 3. Grams of SFA, MUFA, PUFA, $\omega 3$ e $\omega 6$ in $100 \mathrm{~g}$ of game meat and $\omega 6 / \omega 3$ ratio

\begin{tabular}{|c|c|c|c|c|c|c|c|c|}
\hline \multirow{2}{*}{$\mathrm{g} / 100 \mathrm{~g}$} & \multicolumn{2}{|c|}{ Chamois } & \multirow{2}{*}{$\begin{array}{l}\text { Roe deer } \\
\text { Adult } \\
\text { males }\end{array}$} & \multirow[b]{2}{*}{ Yearlings } & \multicolumn{3}{|c|}{ Red deer } & \multirow{2}{*}{$\begin{array}{c}\text { Wild boar } \\
\text { Adult } \\
\text { males }\end{array}$} \\
\hline & Yearlings & $\begin{array}{l}\text { Adult } \\
\text { males }\end{array}$ & & & $\begin{array}{l}\text { Sub-adult } \\
\text { males }\end{array}$ & $\begin{array}{l}\text { Adult } \\
\text { males }\end{array}$ & $\begin{array}{l}\text { Adult } \\
\text { females }\end{array}$ & \\
\hline SFA & 0,76 & 0,75 & 1,17 & 2,96 & 0,71 & 0,17 & 1,41 & 0,85 \\
\hline MUFA & 0,46 & 0,61 & 0,66 & 1,83 & 0,30 & 0,07 & 0,75 & 0,98 \\
\hline PUFA & 0,18 & 0,02 & 0,11 & 0,30 & 0,05 & 0,01 & 0,16 & 0,43 \\
\hline$\omega 3$ & 0,05 & 0,00 & 0,02 & 0,12 & 0,02 & 0,00 & 0,06 & 0,05 \\
\hline$\omega 6$ & 0,13 & 0,01 & 0,08 & 0,18 & 0,03 & 0,01 & 0,10 & 0,37 \\
\hline$\omega 6 / \omega 3$ & 2,37 & 2,60 & 3,83 & 1,60 & 2,03 & 1,66 & 1,68 & 7,52 \\
\hline
\end{tabular}

Table 4. Distribution of $\mathrm{pH}$ values recorded in different species during two intervals: within 240 minutes after slaughter and after 240 minutes after slaughter.

\begin{tabular}{|c|c|c|c|c|c|c|c|c|c|}
\hline & \multicolumn{4}{|c|}{$<240$ minutes \% } & \multicolumn{4}{|c|}{$\geq 240$ minutes $\%$} \\
\hline & & N. & $\mathrm{pH} \leq 5,8$ & $5,8<\mathrm{pH} \leq 6,2$ & $\mathrm{pH}>6,2$ & N. & $\mathrm{pH} \leq 5,8$ & $5,8<\mathrm{pH} \leq 6,2$ & $\mathrm{pH}>6,2$ \\
\hline \multirow[t]{2}{*}{ Chamois } & Best practice & 42 & 71,4 & 21,4 & 7,1 & 219 & 94,5 & 4,6 & 0,9 \\
\hline & Bad practice & 47 & 31,9 & 55,3 & 12,8 & 217 & 72,8 & 23,5 & 3,7 \\
\hline \multirow[t]{2}{*}{ Roe Deer } & Best practice & 27 & 25,9 & 37,0 & 37,0 & 30 & 96,7 & 3,3 & 0,0 \\
\hline & Bad practice & 30 & 6,7 & 50,0 & 43,3 & 21 & 52,4 & 47,6 & 0,0 \\
\hline \multirow[t]{2}{*}{ Red Deer } & Best practice & 37 & 59,5 & 27,0 & 13,5 & 139 & 96,4 & 2,9 & 0,7 \\
\hline & Bad practice & 50 & 36,0 & 44,0 & 20,0 & 106 & 76,4 & 17,0 & 6,6 \\
\hline \multirow[t]{2}{*}{ Wild Boar } & Best practice & 9 & 77,8 & 22,2 & 0,0 & 26 & 88,5 & 7,7 & 3,8 \\
\hline & Bad practice & 5 & 40,0 & 40,0 & 20,0 & 22 & 63,6 & 31,8 & 4,5 \\
\hline \multirow{2}{*}{ All species } & Best practice & 115 & 57,4 & 27,0 & 15,7 & 414 & 94,9 & 4,1 & 1,0 \\
\hline & Bad practice & 132 & 28,0 & 49,2 & 22,7 & 366 & 72,1 & 23,5 & 4,4 \\
\hline
\end{tabular}


was to identify high quality standards for game meat from hunted animals. To reach this goal, $\mathrm{pH}$ measurement has been suggested to be a valid method for the selection of the product after slaughter following good practices of carcass management. It has been observed that proper bleeding by the hunter with a cut directly to the thoracic cavity, can influence the decrease in $\mathrm{pH}$ value in the first 4 hours after culling. If bleeding is conducted in association with proper culling, which doesn't cause agony to the subject, a quality improvement in the final product (meat) has been observed. Animals culled with a nonfatal shot and/or not properly bled showed a slower $\mathrm{pH}$ decrease in the first hours after death.

Furthermore, after 240 minutes postculling, carcasses that were managed using "best practices" showed $\mathrm{pH}$ values lower than 5,8 in $94,9 \%$ of cases, while carcasses managed in an improper way resulted in a slower rate of decrease $\mathrm{pH}$ values lower than 5,8 .
Data collected during the study have demonstrated that carcasses managed with "best practices", but which showed $\mathrm{pH}$ values higher than 5,8 from 4 to 14 hours after culling, belonged to underweight animals compared to the average weight of the species according to age and gender.

\section{Conclusions}

Forecasting parameters for game meat quality are required, since its supply-chain is not supported by national guidelines. Currently, the management of hygienic and sensory quality standards is demanded to the hunters from the shot to the arrival at the slaughterhouse, however they do not always behave properly and adhere to the quality standards, even if they use good practices in the management of the carcass. Furthermore, from a commercial point of view, game meat guidelines are needed, since nutritional parameters of game meat extreme weight loss in red deer males during the mating season, which normally precedes the hunting season.

Moreover, the meat of male deer can be affected by an intense "smell", derived from sexual hormones typical of the mating season, in the weeks immediately following the mating season. Fat and sexual odor negatively affect meat quality, even if good practices in carcass management were applied.

The aim of the studies carried out as a part of the project "Filiera Eco-Alimentare"

\begin{tabular}{|c|c|c|c|c|}
\hline & Degree of freedom & $\mathbf{F}$ & P-value & Partial eta-squared \\
\hline Bled & 1 & 2,935 & 0,031 & 0,891 \\
\hline Agony time & 2 & 0,023 & 0,894 & 0,106 \\
\hline Bled * Agony time & 2 & 0,193 & 0,014 & 0,011 \\
\hline
\end{tabular}

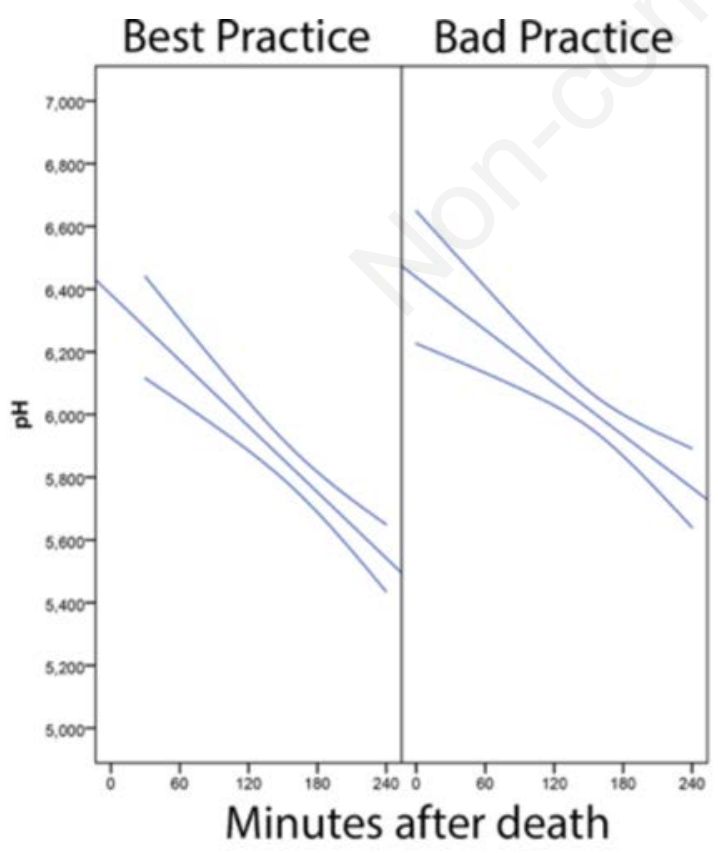

Figure 1. Best practices effect on $\mathrm{pH}$ decrease during four hours after slaughter (Best practices $R^{2}=0,249 ; \quad B a d$ practices $\left.R^{2}=0,120\right)$.

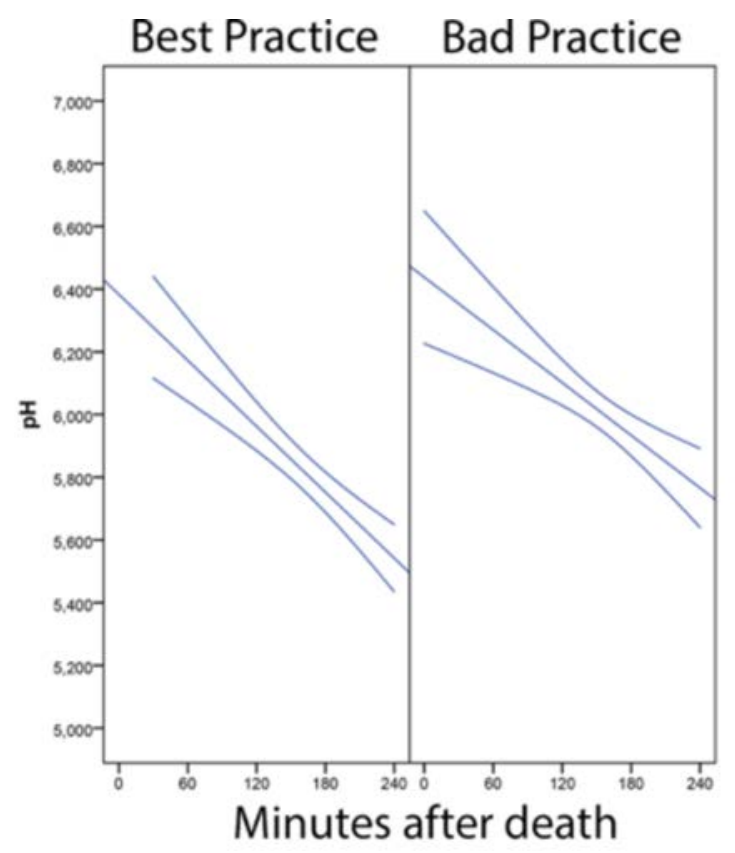

Figure 2. Best practices effect on $\mathrm{pH}$ decrease after four hours after slaughter (Best practices $R^{2}=0,012$; Bad practices $\mathrm{R}^{2}=\mathbf{0 , 0 2 0}$ ). 
vary depending on the species, age, sex and hunting period.

In addition, since in the study area, culling and evisceration are conducted in the field by the hunters, analyses and objective evaluation criteria using low-budget and rapid techniques are needed to determine the product quality before sending the carcasses to authorized centers for meat processing.

Consumer requires that good standards are fulfilled from a hygienic, nutritional, commercial and ethical point of view. To reach this aim, data related to hunting methods, numbers of shots, and possible agony of the culled animal were collected at the hunting district control centers, where every ungulate culled during the hunting season is required to be analyzed according to territorial law. These data can provide good tools when used in combination with $\mathrm{pH}$ values and meat temperature; they can be useful to distinguish high quality products, and they can guarantee that the animal has been culled in accordance with ethical standards. These aspects qualify the supplier and can be used to improve culling procedures.

The pursuit of high-quality standards in wild game meat and in a well-organized supply chain may not only encourage hunters to improve their practices, but can also build a link between the consumer and the territory, thus increasing the value of natural resources and local traditions. Furthermore, a new labelling scheme for the Italian hunted game meat can be created.

\section{References}

Atanassova V, Apelt J, Reich F, Klein G, 2008. Microbiological quality of freshly shot game in Germany. Meat Sci 78:414-9.

Avagnina A, Nucera D, Grassi MA, Ferroglio E, Dalmasso A, Civera T, 2012. The microbiological conditions of carcasses from large game animals in Italy. Meat Sci 91:266-71.

Demartini E, Vecchiato D, Tempesta T, Gaviglio A, Viganò R, 2018. Consumer preferences for red deer meat: A discrete choice analysis considering attitudes towards wild game meat and hunting. Meat Sci 146:168-79.

European Commission, 2004. Regulation of the European Parliament and of the Council of 29 April 2004 laying down specific hygiene rules for on the hygiene of foodstuffs, 853/2004/CE. In: Official Journal, L 139/55, 30/04/2004.
Ferri M, 1998. Il cinghiale: calamità o risorsa? Provincia di Modena. Quaderno di gestione faunistica 2:1-50.

Gaviglio A, Demartini E, Marescotti ME, 2017. The creation of a local supply chain for large wild ungulates meat: opportunities and limitation from an Italian alpine case study. Quality Access to Success 18:215-22.

Gaviglio A, Marescotti ME, Demartini E, 2018. The local value chain of hunted red deer meat: a scenario analysis based on a northern Italian case study. Resources 7:34.

Gill CO, 2007. Microbiological conditions of meat from large game animals and birds. Meat Sci 77:149-60.

Hoffman LC, Ferreria AV, 2000. pH decline of the M. longissimus thoracis of nightcropped Grey Duiker (Sylvicapra grimmia). S Afr J Anim Sci 30:16-7.

Hoffman LC, Wiklund E, 2006. Game and venison - meat for the modern consumer. Meat Sci 74:197-208.

Lawrie RA, 2006. Lawrie's Meat Science. 7th ed. Woodhead Publ. Ltd., Cambridge, UK.

Liepina S, Jemeljanovs A, Konosonoka IH, 2010. Microbiological pollution rate of wild animal (Capreolus capreolus and Cervus elaphus) meat. In: Proceedings of the Latvian University of Agriculture, Jelgava, Latvia, 25:102-15.

Lonergan EH, Zhang W, Lonergan SM, 2010. Biochemistry of postmortem muscle - Lessons on mechanisms of meat tenderization. Meat Sci 86:184-95.

Marescotti ME, Caputo V, Demartini E, Gaviglio A, 2019. Discovering market segments for hunted wild game meat. Meat Sci 149:163-76.

Mustoni A, Pedrotti L, Zanon E, Tosi G, 2002. Ungulati delle Alpi. Biologiariconoscimento-gestione. Ed. Nitida Immagine.

Paulsen P, Bauer A, Vodnansky M, Winkelmayer R, Smulders FJM, 2011. Game meat hygiene in focus. Microbiology, epidemiology, risk analysis and quality assurance. Ed. Wageningen Academic Publishers.

Phillip LE, Oresanya TF, Jacques JSt, 2007. Fatty acid profile, carcass traits and growth rate of red deer fed diets varying in the ratio of concentrate: dried and pelleted roughage, and raised for venison production. Small Ruminant Res 71:215-21.

Piasentier E, Bovolenta S, Viliani M, 2005. Wild ungulate farming systems and product quality. Vet Res Comm 29:6570.
Postolache AN, Boisteanu PC, Lazar R, 2011. Red deer meat (Cervus elaphus): between hunting and necessity. University of Agriculture Science and Veterinary Medicine, Iași, Romania. Medicină Veterinară, Seria Zootehnie 56:265-9.

Ramanzin M, Amici A, Casoli C, Esposito L, Lupi P, Marsico G, Mattiello S, Olivieri O, Ponzetta MP, Russo C, Trabalza Marinucci M, 2010. Meat from wild ungulates: ensuring quality and hygiene of an increasing resource. Ital J Anim Sci 9:318-31.

Russo C, 2005. Carcass and meat quality in fallow deer (Dama Dama): a rewiev. Università degli Studi di Pisa. Annali Fac Med Vet LVIII:207-12.

Sales J, Kotrba R, 2013. Meat from wild boar (Sus scrofa L.): a review. Meat Sci 94:187-201.

Secchiari P, Boselli E, Serra A, Mele M, Savioli S, Buccioni A, Ferruzzi G, Paoletti F, 2001. Intramuscular fat quality of wild fallow deer (Dama dama) meat. Prog Nutr 3:25-30.

Soriano A, Montoro V, Vicente J, SánchezMigallón BF, Benítez S, Utrilla MC, García Ruiz A, 2016. Influence of evisceration time and carcass ageing conditions on wild venison quality. Preliminary study. Meat Sci 114:130-6

Valencak TG, Gamsjäger L, Ohrnberger S, Culbert N, Ruf T, 2015. Healthy n-6/n3 fatty acid composition from five European game meat species remains after cooking. BMC Res Notes 8:273.

Viganò R, Aprico J, Besozzi M, Formenti N, Trogu T, Donazzolo C, Obber F, Ferrari N, Lanfranchi P, 2017. Evaluation of $\mathrm{pH}$ in game meat of red deer hunted in autumn in the Western Italian Alps. In Paulsen P, Bauer A, Smulders FJM. Game meat hygiene Food safety and security. Ed. Wageningen Academic Publishers, pp 241-6.

Wiklund E, Manley TR, Littlejohn RP, 2004. Glycolytic potential and ultimate muscle $\mathrm{pH}$ values in red deer (Cervus elaphus) and fallow deer (Dama dama). Rangifer 24:87-94.

Winkelmayer R, Paulsen P, 2008. Direct marketing of meat from wild game in Austria: a guide to good practice according to Regulations (EEC) 852/2004. Fleischwirtschaft 88:122-5.

Yang B, Chen H, Stanton C, Paul Ross R, Zhang H, Chen YQ, Chen W, 2015. Review of the roles of conjugated linoleic acid in health and disease. J Funct Foods 15:314-25. 